NASA Technical Memorandum 81458

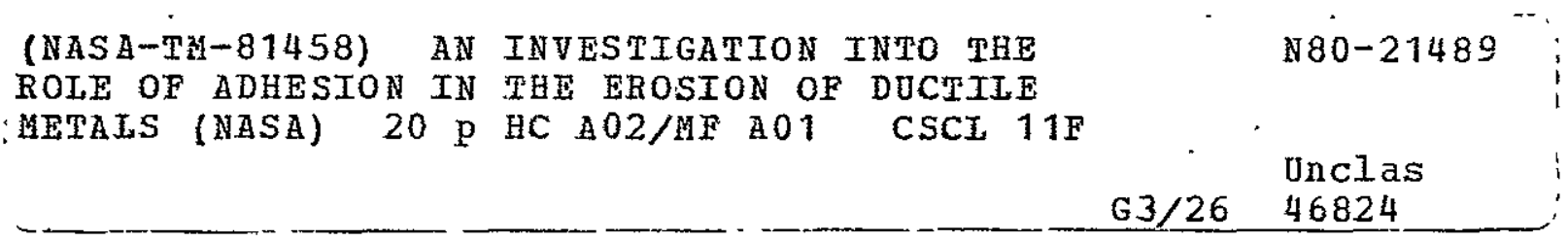

\title{
AN INVESTIGATION INTO THE ROLE \\ OF ADHESION IN THE EROSION OF \\ DUCTILE METALS
}

William A. Brainard and Joshua Salik

Lewis Research Center

Cleveland, Ohio

Prepared for the

Thirty-fifth Annual Meeting of the

American Society of Lubrication Engineers

Anaheim, California, May 5-8, 1980

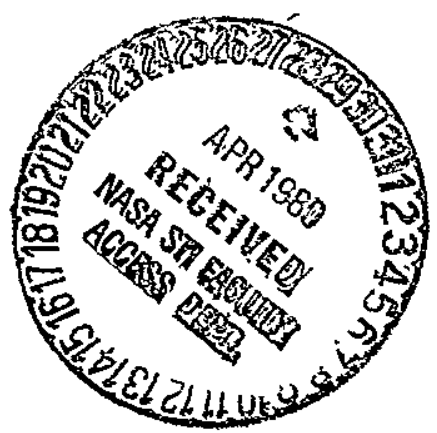




\title{
AN INVESTIGATION INTO THE ROLE OF ADHESION
}

IN THE EROSION OF DUCTILE METALS

\author{
William A. Brainard and Joshua Salik \\ NASA Lewis Research Center \\ Cleveland, Ohio 44135
}

\author{
ABSTRACT \\ Existing theories of erosion of ductile metals based on cutting \\ and deformation mechanisms predict no material removal at normal \\ incidence which is contradictory to experience. Thus, other mechanisms \\ may be involved. The possible role of adhesive material transfer during \\ erosion is investigated by both single particle impingement experiments \\ and erosion by streams of particles. \\ Examination of the rebounding particles as weli as the eroded \\ surfaces yields evidence of a significant adhesive mechanism for the \\ ductile metals investigated.
}




\section{INTRODUCTION}

The erosion of materials by streams of solid particles presents serious problems in aircraft (ref. 1) and coal gasification processes (ref. 2) and thus has been the subject of growing interest in recent years. Both theoretical (ref's. 3 to 5) and experimental (refs. 6 to 14) studies aimed at elucidating the mechanisms involved were conducted. Two types of erosion mechanisms were considered in those studies: a cutting wear mechanism associated with forces parallel to the eroded surface (ref. 3) and a so-called deformation wear mechanism associated with forces normal to the surface (ref. 6). Erosion theories based on those two mechanisms were able to explain some features of the erosion behavior of ductile metals, notably the occurrence of a maximum in the erosion rate at an attack angle of $\sim 17^{\circ}$. However, whereas the theory predicts negligible or no erosion of ductile metals at normal incidence, the experimental results show substantial erosion under these conditions, amounting to $\sim 50 \%$ of the erosion rate at $17^{\circ}$ for AI eroded by $\mathrm{Al}_{2} \mathrm{O}_{3}$ particles. Although some authors (refs. 11, 12) have offered explanations for this discrepancy it seems quite possible that some mechanisms which are actually involved in erosion have been overlooked.

In sliding wear one of the major mechanisms of material removal is adhesive material transfer (ref. 15). Since many of the conditions that occur in sliding, namely intimate interfacial contact between the interacting bodies due to rupture of surface films and flow of material from the contact zone due to compressive stress, also exist in erosion, it is likely that adhesive material transfex is also one of the mechanisms contributing to erosive wear. The objective of the study 
reported herein was to investigate this possibility. Two types of experiments were conducted - single particle impact experiments and erosion by means of continuous streams of small particles.

\section{MATERIALS}

Three types of target materials were used in this study: $6061 \mathrm{Al}$ alloy which had been annealed for 3 hours at $420^{\circ} \mathrm{C}$; ASTM B152-76 copper which had been annealed for 3 hours at $500^{\circ} \mathrm{C}$ and ASTM A108 steel to which no heat treatment was applied.

\section{APPARATUS AND PROCEDURE}

The gun used for the single particle impact experiments was of the same design as the one used by Hutchings and Winter (ref. 16) with a barrel length of $20.5 \mathrm{~cm}$ using nitrogen as the driving gas and hollow teflon sabots (c.a. 2.7 grams by weight) for holding the projectile. The projectiles were hardened $\left(62-65 \mathrm{R}_{\mathrm{c}}\right.$ ) AISI 52100 bearing steelballs of $3.2 \mathrm{~mm}$ diameter. Two solar cells placed $5 \mathrm{~cm}$ apart were, used for measuring the projectile velocity. A schematic of the apparatus is shown in Figure 1. The gun was operated at pressures up to $4 \mathrm{MPa}$ with aluminum rupture diaphragms 0.06 to $0.25 \mathrm{~mm}$ thick resulting in particle velocities from 85 to 180 meters per second.

A commercial abrasive blasting unit was used for the study of erosion by streams of particles. The unit used a gas nozzle to accelerate the erodant particles. The eroding particles were glass spheres of $15 \mu \mathrm{m}$ average diameter and $\mathrm{Al}_{2} \mathrm{O}_{3}$ particles $50 \mu \mathrm{m}$ in size and of irregular shape. The carrier gas was Argon at 80 psi. Although no measurement of particle velocity or flow rate was made in this case, 
there is evidence that the particle velocity was much lower than in the single impact experiments (ref. 17).

Following impact the eroding particles or steel spheres were collected and examined in a scanning electron microscope augmented with energy-dispersion $\mathrm{x}$-ray analyzex. The impacted metal surfaces were also examined both optically and in the SEM.

\section{RESULTS AND DISCUSSION \\ Single Impact Experiments}

The $x$-ray emission spectrum obtained from a virgin ball which had not been impacted is shown in Figure 2. The peaks at $6.4 \mathrm{keV}$ and $7.1 \mathrm{keV}$ are, respectively, the $\mathrm{K}_{\alpha}$ and $\mathrm{K}_{\beta 1}$ emissions of Fe. The peak at $1.7 \mathrm{keV}$ is the $\mathrm{Si} \mathrm{K}_{\alpha}$ line. Figure 3 shows the $\mathrm{x}$-ray emission spectrum of a ball that had been shot at an annealed 6061 Al alloy at a speed of $107 \mathrm{~m} / \mathrm{sec}$. A peak at $1.5 \mathrm{keV}$ due to $\mathrm{Al} \mathrm{K}_{\alpha}$ emission is clearly seen, indicating transfer of Al from the target onto the projectile. However, the amount of material transferred in this case was too small to be observed in the SEM and it was necessary to go to higher impact velocities in order to gain information about the morphology of the transferred material.

Figure $4(a)$ is an SEM micrograph of a portion of the surface of a ball which had been shot at a 6061 target at a speed of $147 \mathrm{~m} / \mathrm{sec}$. It shows that target material which is transferred to the projectile forms a continuous layer on its surface. Figure $4(c)$ is the $x$-ray emission spectrum taken from the area covered by the layer of transferred material. Note that the $\mathrm{Fe} \mathrm{K}_{\alpha}$ peak at $6.4 \mathrm{keV}$ obtained from the covered area is higher than the one obtained from the uncovered area 
which is shown in Figure $4(\mathrm{~b})$. This is due to the fact that most of the x-ray emission takes place at some depth underneath the surface and thus the $x$-ray is absorbed on its way out of the sample (ref. 18). Since the absorption coefficient of $\mathrm{Al}$ for $\mathrm{Fe} \mathrm{K}_{\alpha}$ radiation which is $252.4 \mathrm{~cm}^{-1}$ (ref. 19) is lower than that of Fe for the same radiation, which is $560.0 \mathrm{~cm}^{-1}$ (ref. 19) the absorption with the Al layer present is smaller and thus higher intensity is obtained. Using Lambert's law

$$
I=I_{0} \exp (-\mu t)
$$

where $I_{0}$ is the intensity of the emitted $x$-ray, $I$ is its intensity after traversing a layer of thickness $t$ and $\mu$ is the absorption coefficient, one can use the intensity ratio in these two cases to get a rough estimate of the thickness of the Al layer, yielding a value of the order of $3 \mu \mathrm{m}$. By measuring the diameter and depth of the crater formed on the target by the impacting ball, the area of intimate contact between the ball and the target was calculated and found to be $0.32 \mathrm{~cm}^{2}$ thus yielding a value of $2.610^{-4}$ gram for the amount of target material transferred per particle, i.e, an erosion ratio as high as $210^{-3}$ (mass removed/mass impinged). Since this is of the same order of magnitude as the total erosion rate observed for the same conditions, it may be inferred that adhesive material transfer plays an important role in the erosion process and thus should be taken into account in theoretical treatments of erosion.

The overall surface morphology of the ball after impact is schematically illustrated in Figure 5 where two regions are shown: the upper one which is the one that had been in direct contact with the target during impact and is covered with the layer of transferred material and the lower 
one is that which had not been in contact with the target and is "clean". The covered part also contains occasional chunks of target material. An example of such a chunk is shown in Figure 6, together with the corresponding AI $\mathrm{K}_{\alpha}$ emission map.

Adhesive material transfer is not limited to $A l$ as can be seen from Figure 7 which shows the ball surface and the corresponding $\mathrm{Cu} \mathrm{K}_{\alpha}$ map obtained from a ball which had been shot at an annealed $\mathrm{Cu}$ target into a region previously impacted several times. The $\mathrm{x}$-ray map clearly shows a rather heavy transferred film of copper onto the steel surface.

Further evidence of adhesion was obtained from examination of the impacted copper surface. Figure 8 is a micrograph taken from the bottom of a crater formed on an annealed $\mathrm{Cu}$ target by the impact of a steel ball at140 meters per second, and it can be readily seen that tensile fracture of target material had taken place. The tensile fracture is a result of adhesion forces between the target and the rebounding particle.

\section{Erosion by Continuous Streams of Particles}

In order to verify the role of adhesive material transfer in more real situations, erosion tests using continuous streams of particles were also conducted. The erodant particles rebounding from the target were collected and examined by means of the energy-dispersive $x$-ray analyzer. Figure 9 is the $x$-ray emission spectrum obtained from $\mathrm{Al}_{2}{ }_{3}$ particles which had been used for the erosion of an annealed Cu target. A peak at $8 \mathrm{keV}$ due to transferred $\mathrm{Cu}$ is clearly seen.

Another technique employed in this study is ferrography which is used in lubrication research to separate ferromagnetic wear debris from liquid lubricants by means of a magnetic field and provides a means of 
of observing the shape and size of worn material. Analysis of the wear debris has been shown to yield information regarding the mechanisms involved (ref. 20). The method is fast and simple but it is limited to the analysis of ferromagnetic materials. ASTM A108 steel samples were eroded by glass beads and the used erodant particles were captured. These particles were then mixed with a light mineral oil and passed through the ferrograph. Figure 10 shows a scanning electron micrograph of the eroded debris together with the corresponding $\mathrm{Fe} \mathrm{K}_{\alpha}$ x-ray emission map confirming the occurrence of adhesive material transfer from the target onto the glass bead.

\section{CONCLUSIONS}

It has been demonstrated that adhesive material transfer constitutes a mechanism of material removal in the exosion of ductile metals. Since erosion theories based on cutting and deformation mechanisms were unable to explain the occurrence of erosion of ductile metals at normal incidence, this finding accounts, as least partially, for the difference between theoretical and experimental results.

Adhesively transferred material forms a continuous layer on that part of the impinging particle which was in intimate contact with the target. In addition, adhesion forces cause material removal via tensile fracture resulting in chunks of transferred material on the erodant particles. 


\section{REFERENCES}

1. Schmitt, G. F., Jr., "Impact Erosion - A Serious Environmental

Threat to Aircraft and Missiles," ASME Paper 75-ENAS-45 (JuIy 1975).

2. McGee, J. P., Goff, G. B., Liberatore, A. J., and strimbeck, D. C.,

"Turbine Blade Wear by Coal Ash in Working Fluid at $1200^{\circ} \mathrm{F}$,"

Bureau of Mines, BM-RI-7255 (1969).

3. Finnie, I., "Erosion of Surfaces by Solid Particles," Wear, 3 , pp. 87-103 (1960).

4. Bitter, J. G. A., "A Study of Erosion Phenomena. Pt. I and Pt. II," Wear, 6, Pt.I, pp. 5-21, Pt. II, pp. 169-190 (1963).

5. Finnie, I. and McFadden, D. H., "On the Velocity Dependence of the Exosion of Ductile Metals by Solid Particles at Low Angles of Incidence," Wear, 48, pp. 181-190 (1978).

6. Neilson, J. H. and Gilchrist, A., "Erosion by a Stream of Solid Particles," Wear, 11, pp. 111-122 (1968).

7. Tilly, G. P., "Erosion Caused by Airborne Particles," Wear, 14, pp. 63-79 (1969).

8. Goodwin, J. E., Sage, W., and Ti1ly, G. P., "A Study of Erosion by Solid Particles," Proc. Inst. Mech. Eng. (London), Part 1, 184, 15, Pp. 279-292 (1970).

9. Tilly, G. P. and Sage, W., "The Interaction of Particle and Material Behavior in Erosion Processes," Wear, 16, pp. 447-465 (1970).

10. Smeltzer, C. E., Compton, W. A., Gulden, M. E., . and McElmury, S. S., "Mechanisms of Sand and Dust Erosion in Gas Turbine Engines," Solar, RDR-1625-6 (1970). (USAAVLABS-TR-70-36, AD-876584).

11. Sheldon, G. I. and Kanhere, A., "An Investigation of Impingement Erosion Using Single Particles," Wear, 21, pp. 195-209 (1972). 
12. Tilly, G. P., "A Two Stage Mechanism of Ductile Erosion," Wear, 23, pp. 87-96 (1973)。

13. Hutchings, I. M。 and Winter, R. E., "Particle Erosion of Ductile Metals: A Mechanism of Material Remova1," Wear, 27, pp. 121-128 (1974)

14. Hutchings, I. M., Winter, R. E., and Field, J. E., "Solid Particle Erosion of Metals: The Removal of Surface Material by Spherical Projectiles," Proc. Roy. Soc. (Iondon), Ser. A, 348, 1654, pp. 379-392 (1976).

15. Bowden, F. P. and Tabor, D., The Friction and Lubrication of Solids, Oxford University Press, Iondon (1950), p. 306.

16. Hutchings, I. M. and Winter, R. E., "A Simple Sma11-Bore Laboratory Gas Gun," J. Phys. E: Sci. Instrum., 8, pp.84-86 (1975).

17. Brainard, W. A. and Salik, J., "A Scanning Electron Microscope Study of the Normal Impingement Erosion of Ductile Metals," NASA TP-1609 (1980)

18. Brandon, D. G., Modern Techniques in Metallography, D. Van Nostrand Co., Princeton, NJ (1966), pp. 138-140.

19. Hodgman, C. D., Ed., Handbook of Chemistry and Physics, Chemical Rubber Co., Cleveland, Thirty-Eighth Edition (1956), p. 2428. 20. Jones, W. R., Jr. and Parker, R。 J., "Ferrographic Analysis of Wear Debris Generated in Accelerated Rolling Element Fatigue Tests," ASIE Trans。, 22, pp.37-45 (1979)。 
ORIGINAL PAGE IS

OF POOR QUALITY

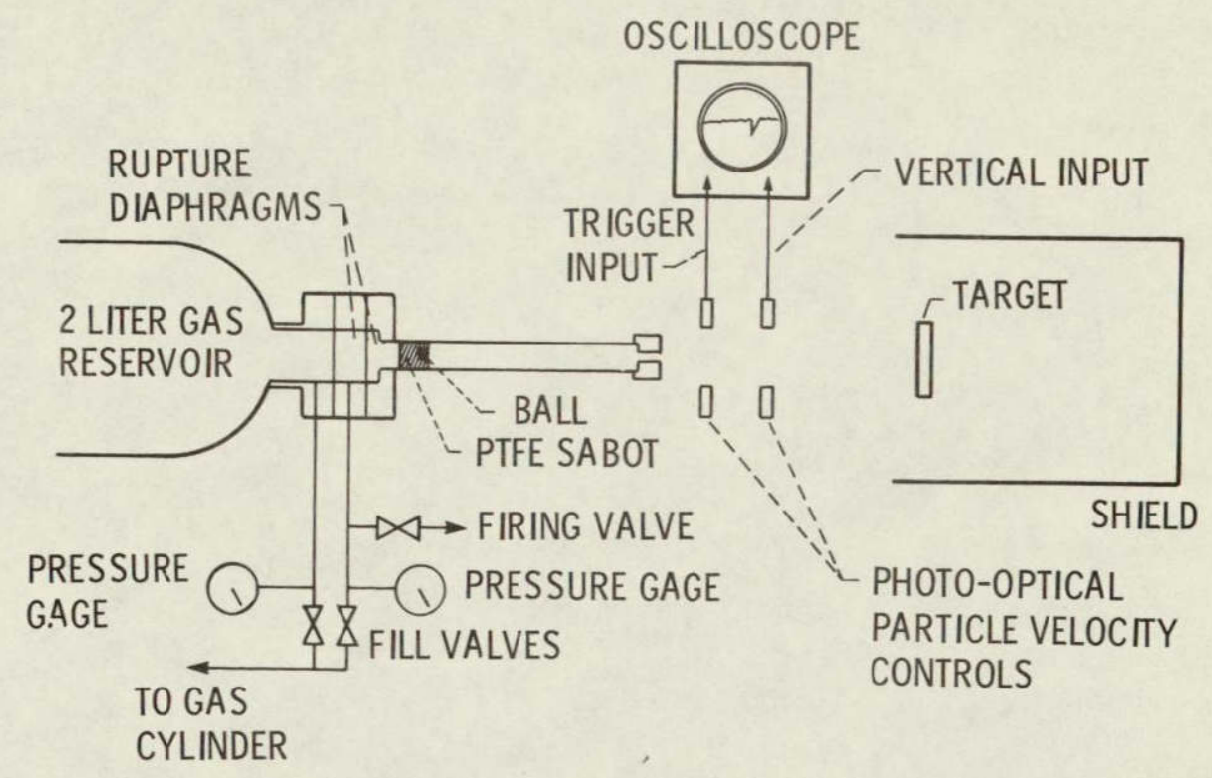

Figure 1. - Schematic of single particle impingement apparatus.

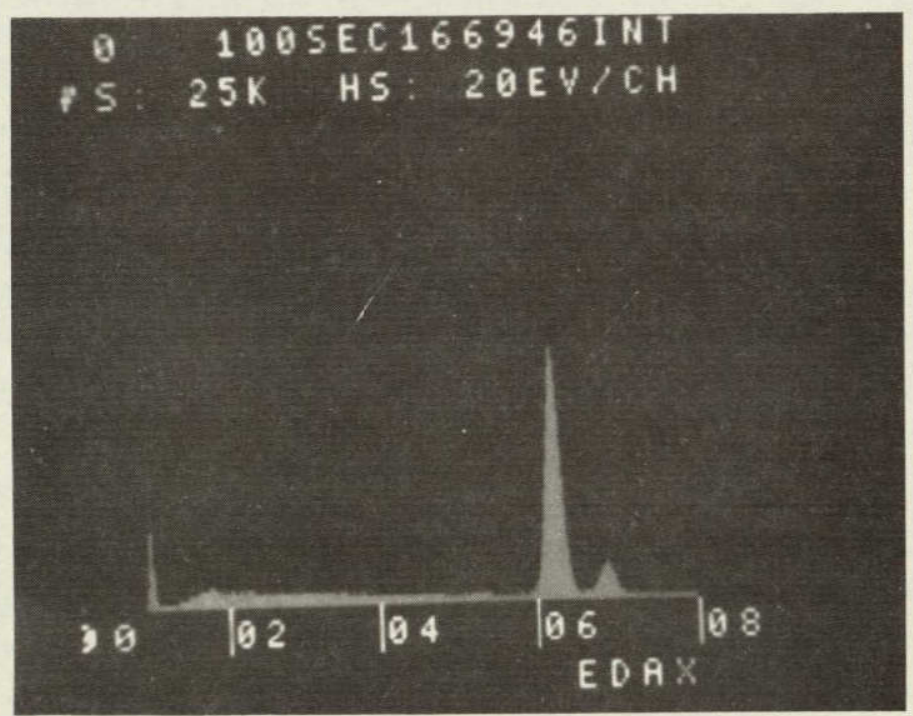

Figure 2. - X-ray emission spectrum from a virgin ball. 
ORfGINAL PAGE IS

OF POOR QUALITY

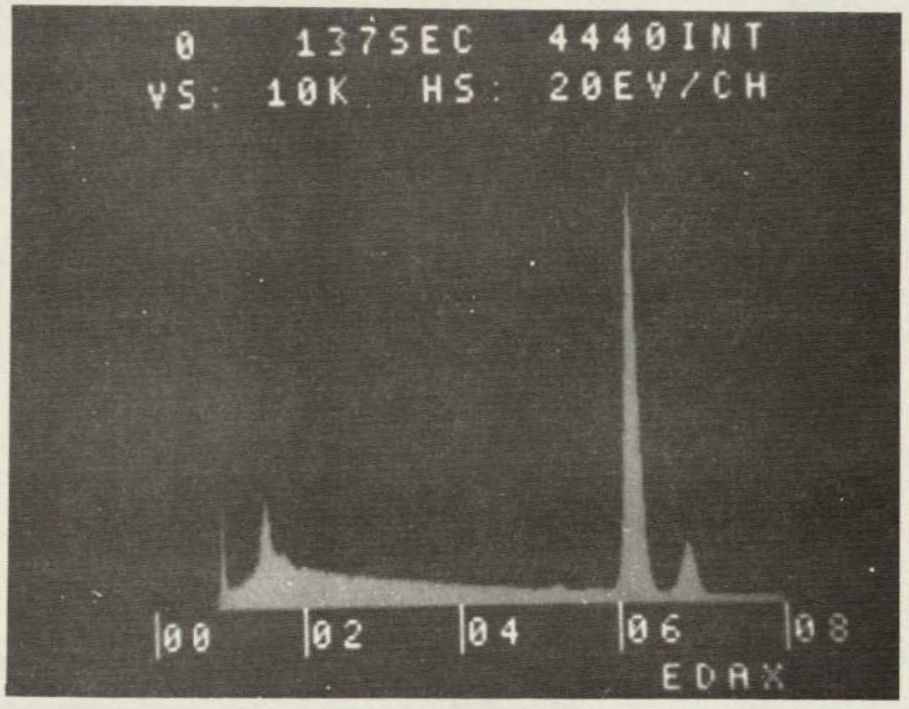

Figure 3. - X-ray emission spectrum from a ball after hitting a $606 \mathrm{l}$ aluminum target at a speed of 107 $\mathrm{m} / \mathrm{sec}$.

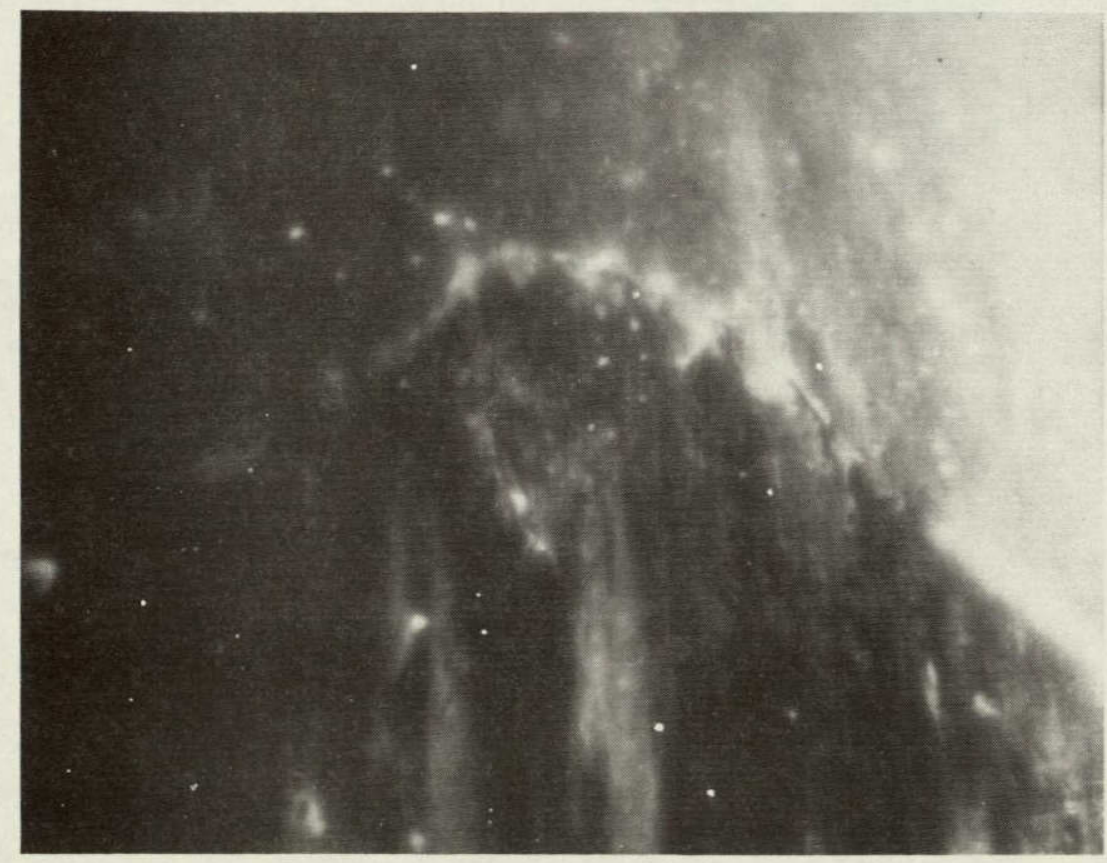

(a) AN SEM MICROGRAPH OF A BALL AFTER HITTING A 6061 ALUMINUM TARGET AT $180 \mathrm{~m} / \mathrm{sec}$.

Figure 4. 
ORIGINAL PAGE IS

OF POOR QUALITY

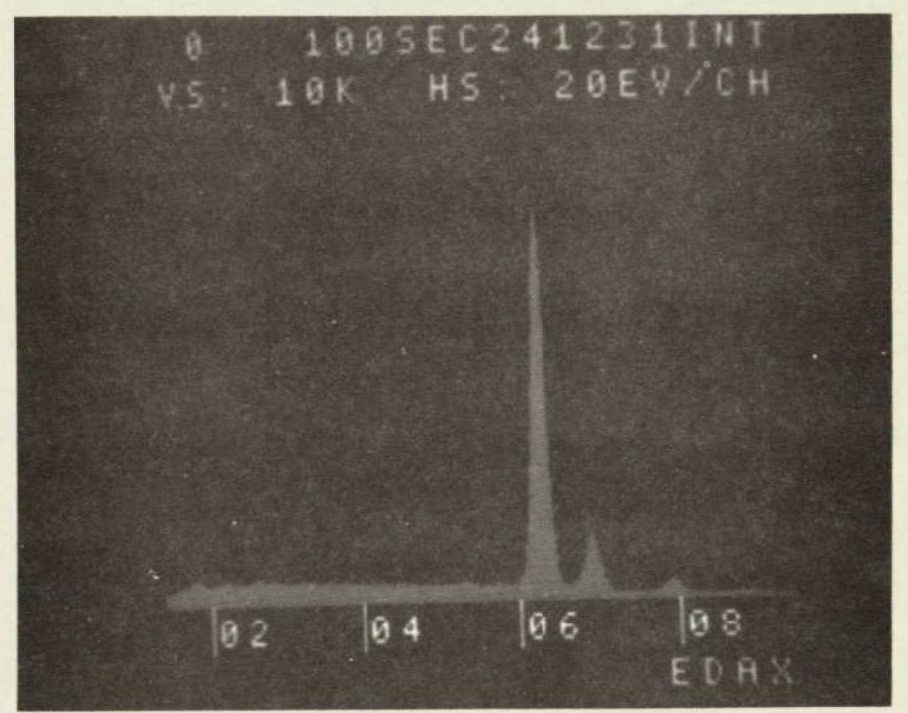

(b) X-RAY EMISSION SPECTRUM FROM UPPER PART OF (A).

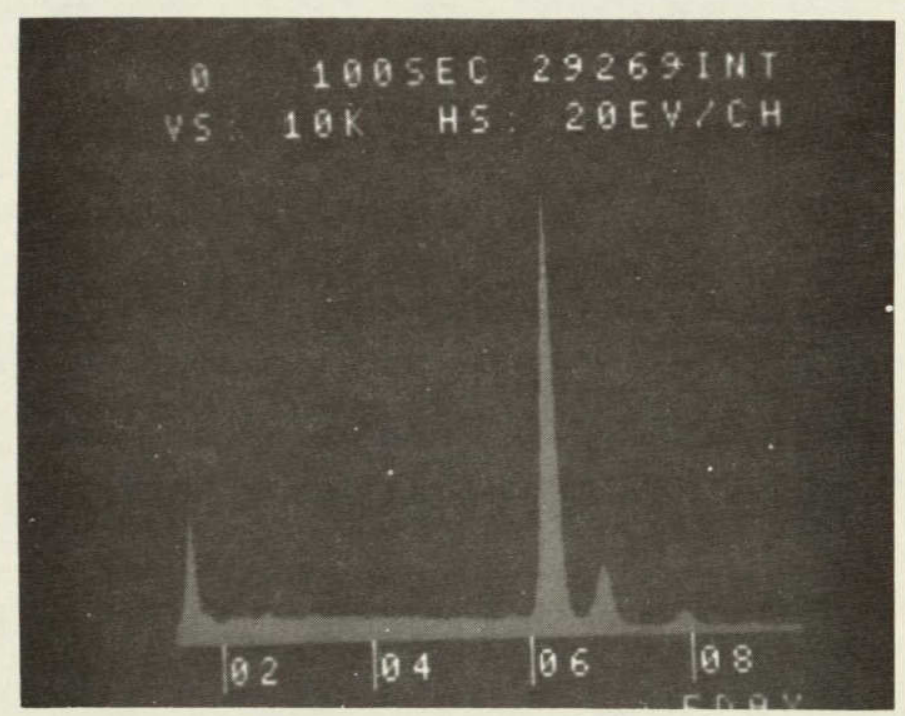

(C) X-RAY EMISSION SPECTRUM FROM LOWER PART $O F(A)$.

Figure 4. Concluded. 


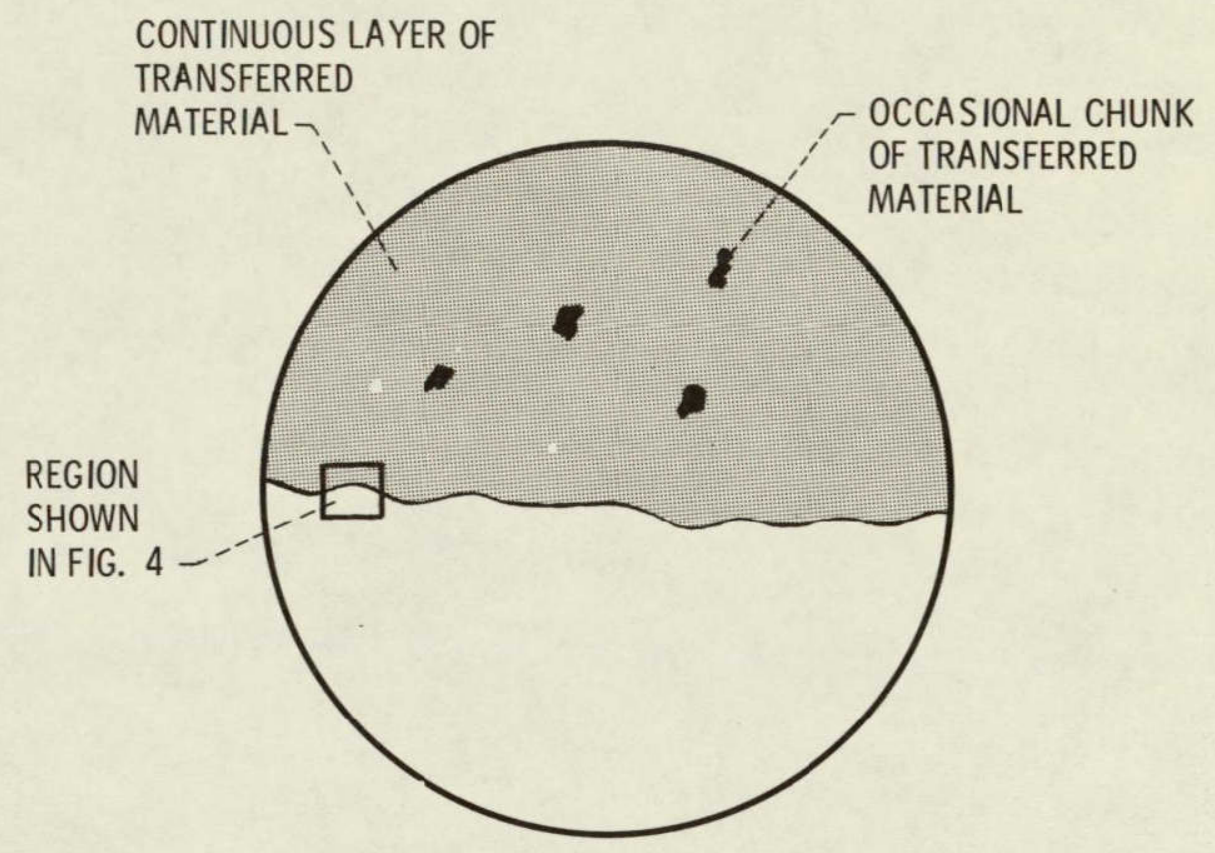

Figure 5. - Schematic illustration of steel ball surface after impinging on annealed 6061 aluminum surface at $180 \mathrm{~m} / \mathrm{sec}$. 


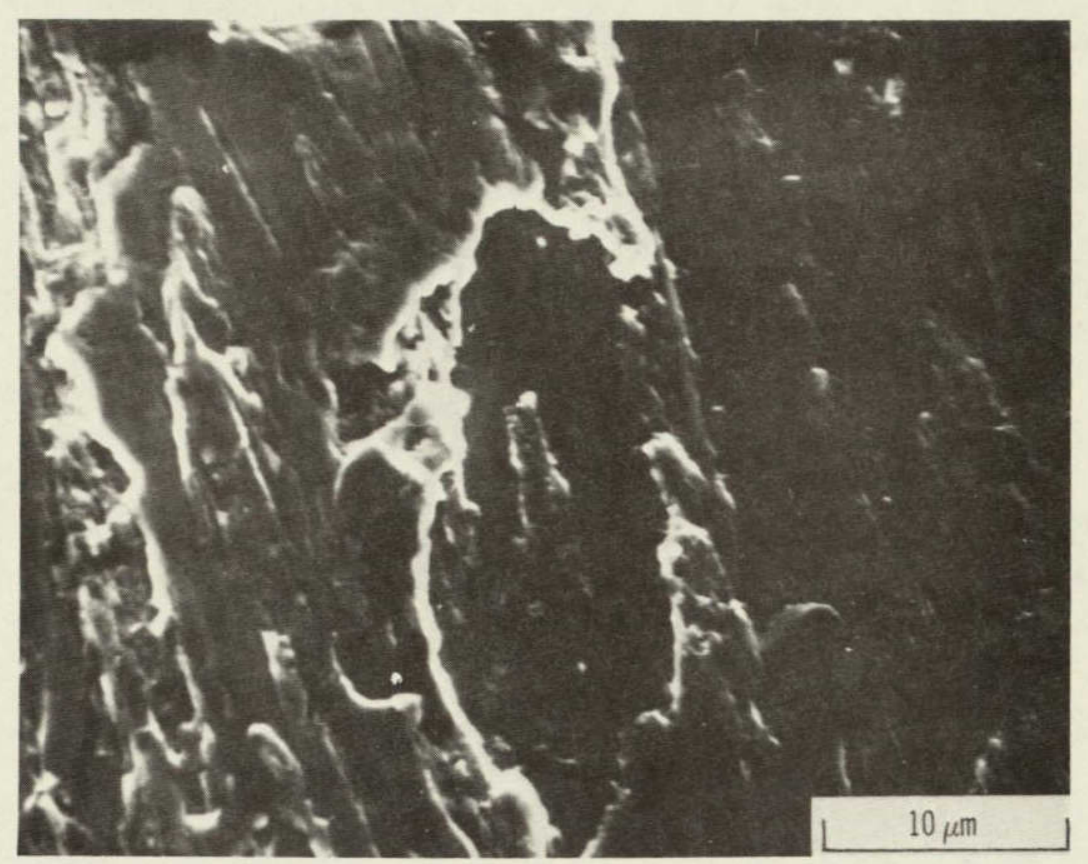

(a) AN SEM MICROGRAPH OF A $3.2 \mathrm{~mm}$ DIAMETER STEEL BALL AFTER IMPACT AT $140 \mathrm{~m} / \mathrm{sec}$ INTO ANNEALED COPPER TARGET PREVIOUSLY IMPACTED 4 TIMES.

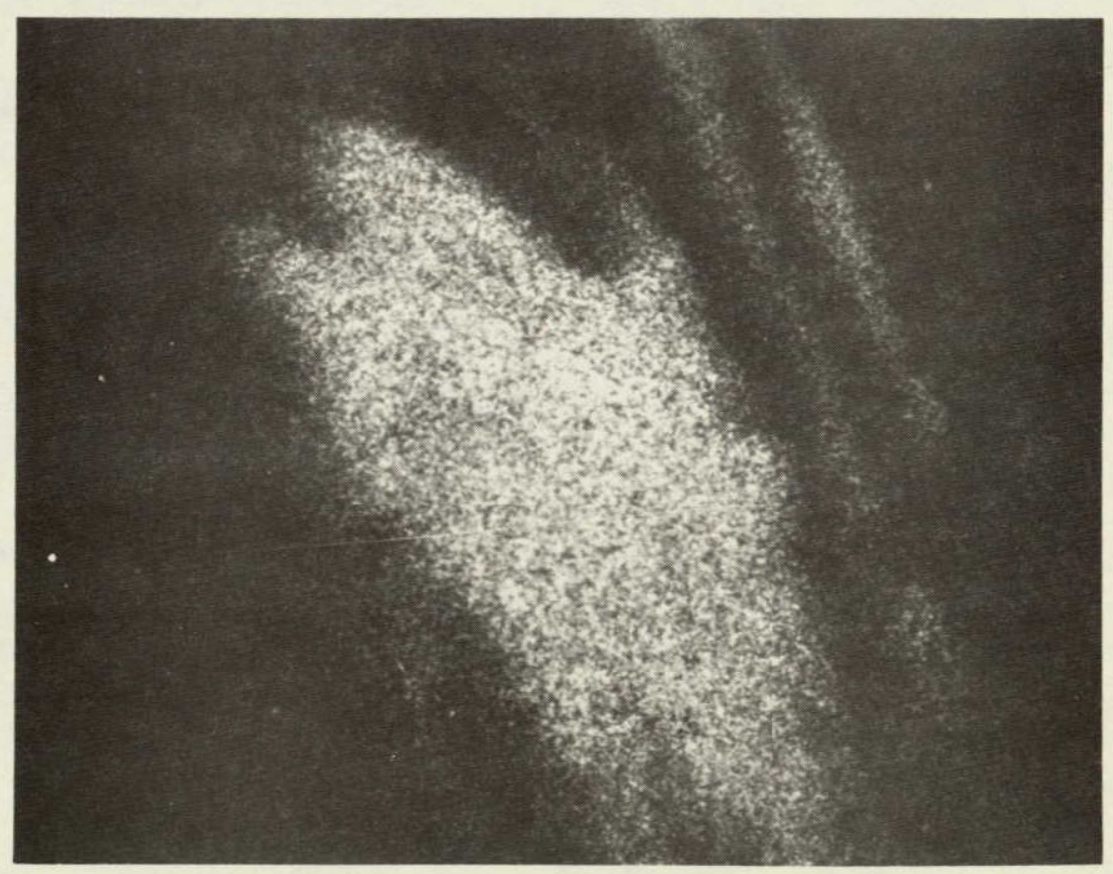

(b) AN AI $K_{\alpha} X$-RAY EMISSION MAP OF THE REGION SHOWN IN (A). Figure 6. 


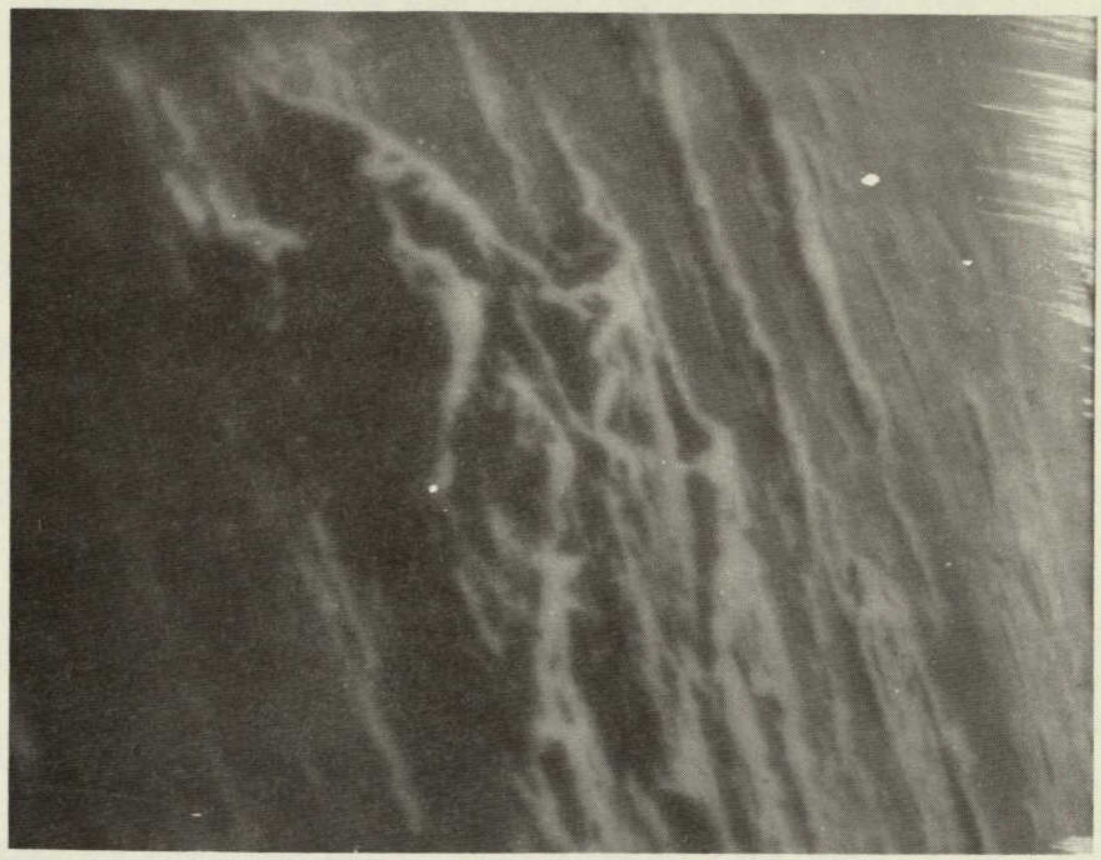

(a) AN SEM MICROGRAPH OF A CHUNK OF TRANSFERRED TARGET MATERIAL AFTER HITTING A 6061 ALUMINUM TARGET AT $180 \mathrm{~m} / \mathrm{sec}$.

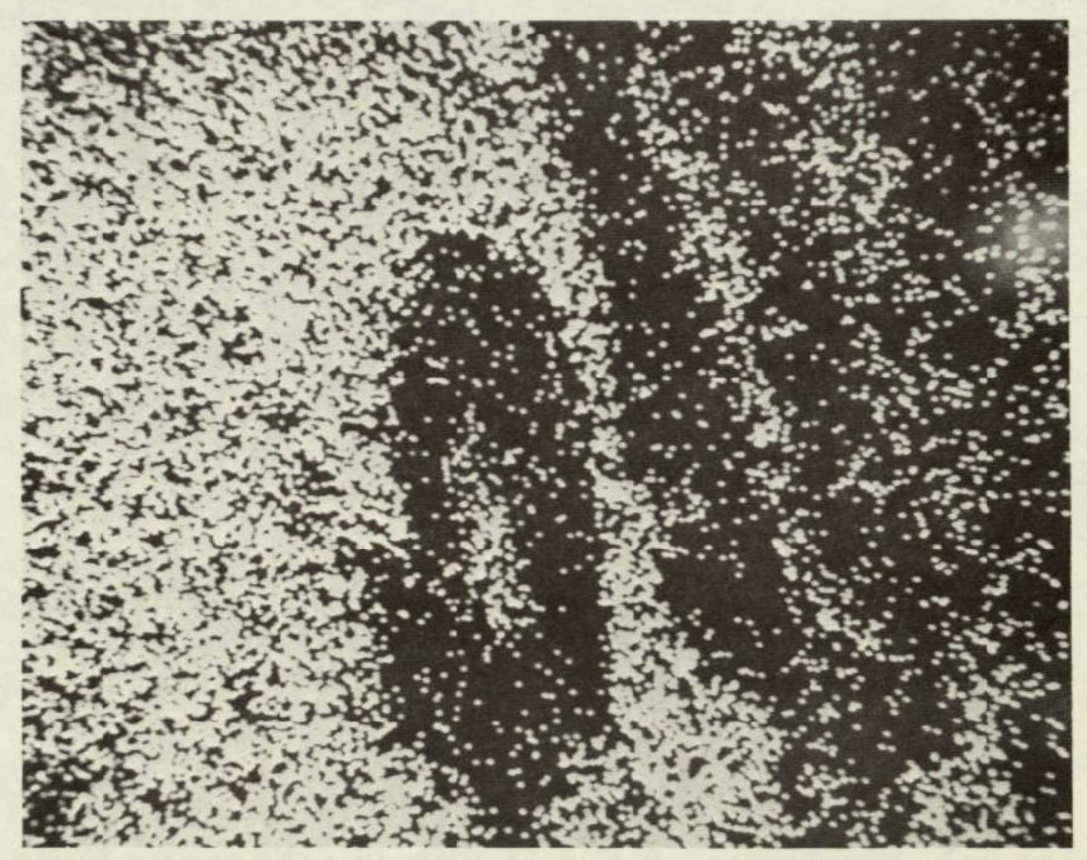

(b) A Cu K $\alpha$ X-RAY EMISSION MAP OF THE REGION SHOWN IN (A).

Figure 7. 

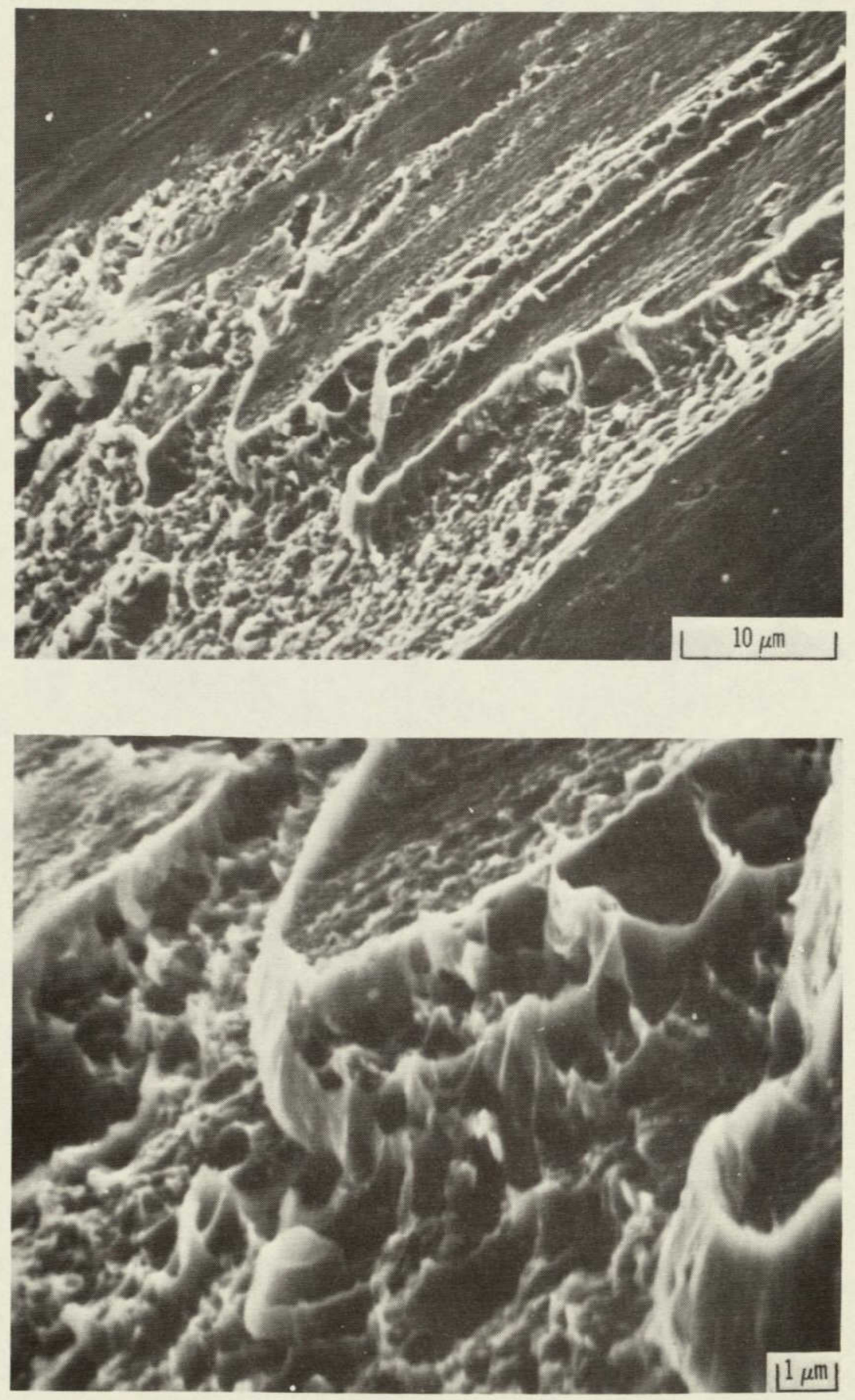

Figure 8. - SEM micrographs of a crater in annealed copper surface after impacts by $3.2 \mathrm{~mm}$ diameter steel ball at $140 \mathrm{~m} / \mathrm{sec}$. 


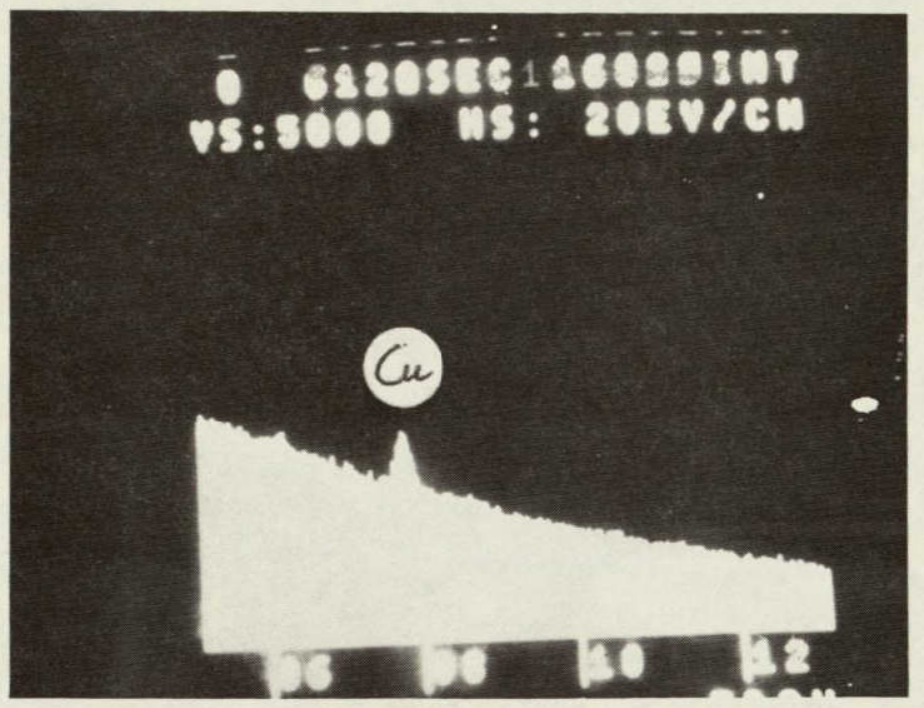

Figure 9. - Energy-dispersive spectrum of $\mathrm{Al}_{2} \mathrm{O}_{3}$ erodant particles after impacting against annealed copper. 
ORIGINAL PAGE IS

OF POOR QUALITY

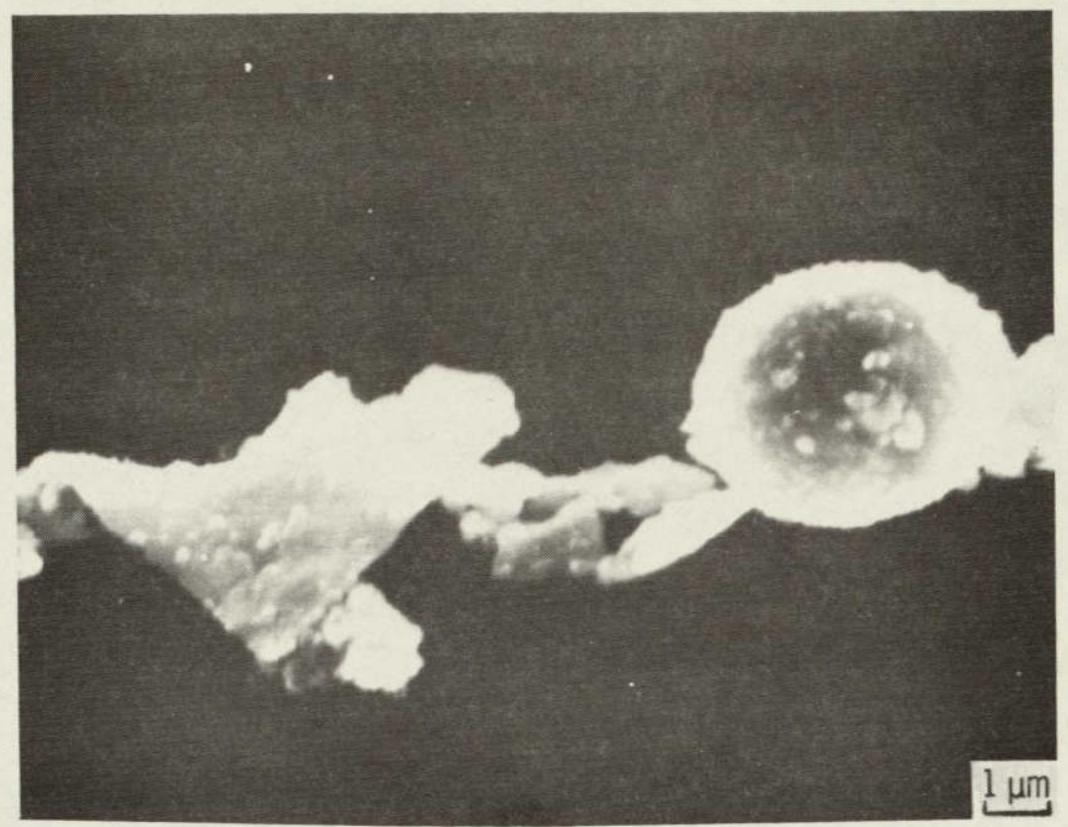

(a) FERROGRAPHIC WEAR DEBRIS OBTAINED FROM THE EROSION OF Al08 STEEL.

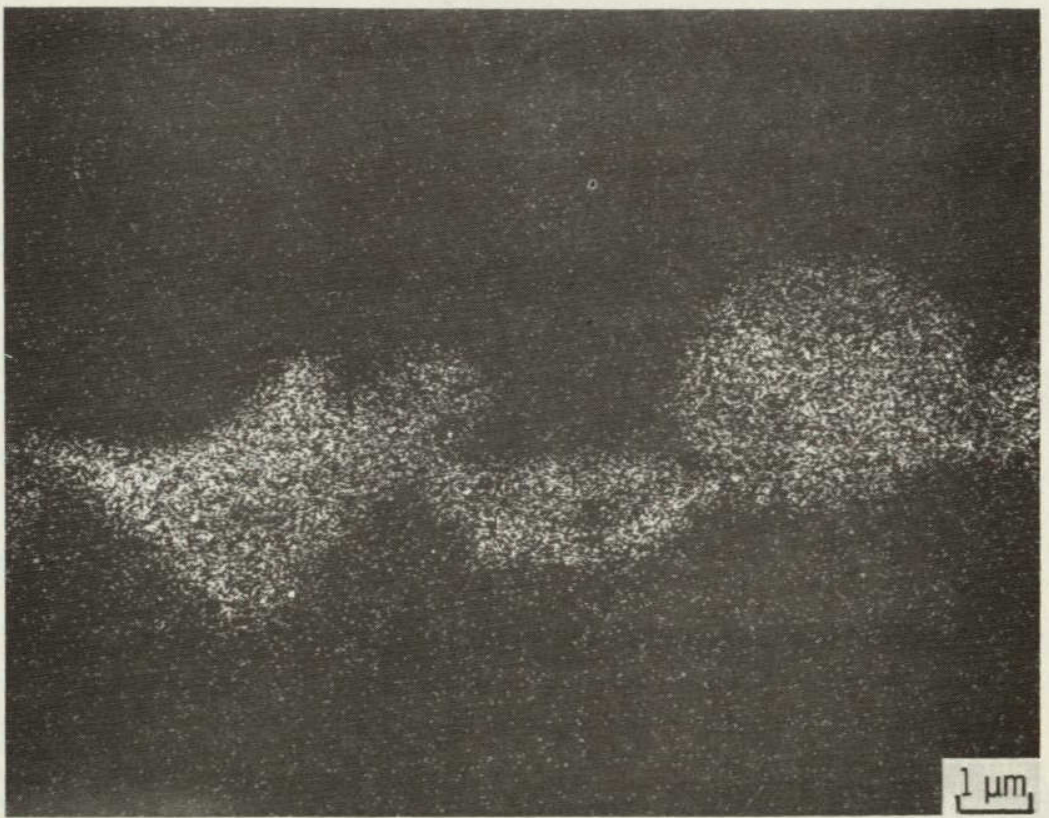

(b) Fe $K_{a}$ EMISSION MAP OF (A).

Figure 10. 
National Aeronautics and Space Administration

SPECIAL FOURTH CLASS MAIL BOOK
Postage and Fees Paid

National Aeronautics and Space Administration

NASA-451

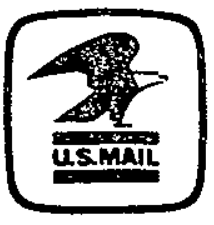

Washington, D.C.

20546

Official Business

Penaity for Private Use, $\$ 300$ 